\title{
WORKING CAPITAL TURNOVER, OPERATIONAL COST RATIO, AND INVENTORY TURNOVER ON COMPANY PERFORMANCE
}

\author{
${ }^{123}$ Ajeng Eka Pratama, Muhaimin Dimyati, Yanna Eka Pratiwi \\ Departement of Accountinng, STIE Widya Gama Lumajang ${ }^{1}$ \\ Departement of Accountinng, STIE Mandala, Jember ${ }^{2}$ \\ Departement of Accountinng, Universitas merdeka Surabaya ${ }^{3}$ \\ Email: ekajeng22@gmail.com
}

\section{A R T ICLE INFO}

Date of entry:

18 Oktober 2019

Revision Date:

29 November 2019

Date Received:

20 December 2019

\begin{abstract}
A B S T R A C T
This study aims to determine the effect of working capital turnover, operational cost ratio, inventory turnover on the performance of UD. Firmansyah. The data used are the financial statements for the period 20152018. The data obtained were analyzed using multiple linear regression. The number of samples used was 48 samples. Partially the results show that working capital turnover and inventory turnover do not have a significant effect on company performance, while the ratio of operating costs has a significant effect on company performance. Meanwhile, simultaneously the research shows that working capital turnover, operational cost ratio, and inventory turnover have a significant effect on company performance. The coefficient of determination in this study is 0.165 , which means that $16.5 \%$ of the company's performance can be explained by working capital turnover, operational cost ratio, and inventory turnover variables. At the same time, the remaining $83.5 \%$ is explained by other factors not included in this study.
\end{abstract}

Keywords: working capital turnover, operational cost ratio, inventory turnover, company performance.

Cite this as: Pratama, A. E, Dimyati, M., Murniati, W. (2020). WORKING CAPITAL TURNOVER, OPERATIONAL COST RATIO, AND INVENTORY TURNOVER ON COMPANY PERFORMANCE. Assets : Jurnal Ilmiah Ilmu Akuntansi, Keuangan dan Pajak, 4(1), 42-49

\section{INTRODUCTION}

According to Kusumo and Dermawan (2018), a company is an organization established with the main objective of making a profit in order to improve the welfare of its owners or shareholders. In carrying out its activities, companies need capital to be spent daily for the continuity of company activities. Abdul Halim (2015: 159) argues that working capital consists of several elements, namely cash, accounts receivable and inventories. To find working capital turnover, the sales formula is used divided by net working capital. Every activity carried out by the company always requires funds, both to finance daily operational activities and to finance long-term investments. In the company's operational activities, an important aspect of capital is the cost to support the company's activities. Costs are an important element that must be sacrificed for the benefit and smooth running of the company's operational activities, Ernawati (2015). 
Carrying out its activities, companies engaged in trading incur operational costs. According to Adnyana (2016), operational costs are the costs needed for smooth sales and marketing, while costs are the source of funds spent or used to obtain the revenue expected by the company in achieving its goals. A trading company needs to have a stock to keep the company's operations running smoothly. In trading companies, they must pay attention to the inventory aspect so that if one day there is an increase in consumer demand, the company is not confused because it already has inventory in the warehouse. However, in managing inventory, it must be precise so that there is no excessive or overloaded inventory which will result in additional maintenance costs for merchandise.

How to measure how efficient a company is in managing and selling its merchandise inventory by knowing the inventory turnover during one period. According to Kuswadi (2005: 82), inventory turnover is the ratio of the cost of goods manufactured to the average inventory during a certain period. Aims to measure the efficiency of the company in managing and selling its inventory. According to Kuswadi (2005: 83), the inventory turnover ratio describes the speed of inventory turnover so that the greater the ratio, the better. The higher this turnover, the shorter or better the average time between investment in inventory and sales transactions. This shows that the higher the level of demand or sales of the company's products, and the more efficient the work of the inventory management team, the higher the profit. A high inventory turnover rate can also provide an indication of an inventory shortage, which can lead to lost sales orders. If the company's funds are tied to inventory excessively, inventory turnover will below. If the company is not successful in marketing its products, the revenue from sales will decrease, while the inventory will increase. According to Rosyafah (2016: 98), from the perspective of outside management, the best step that can be taken is to link the recorded inventory value with net sales or cost of goods sold, which is called the inventory turnover ratio. Generally used as inventory value is the average value of inventory, there are also those who use the ending inventory value, especially in fast-growing companies where inventory is stacked to support the expected increase in sales. A fast inventory turnover indicates that the company is able to manage its inventory efficiently and also shows that the inventory can be sold quickly so that the company makes a profit. In determining the average inventory, we can divide the amount of inventory ending and beginning of the year by two (2). As long as the amount of inventory on hand is stable, this average calculation will be accurate enough for analysis.

The company is said to be successful in achieving its objectives measured by how effective and efficient the company's performance is in achieving its goals. According to Mega (2016), performance is an achievement achieved by a person in carrying out the tasks and work assigned to him. According to Mega (2016), work performance or performance is the result or level of success of a person as a whole during a certain period in carrying out a task compared to various possibilities, such as standard work results, targets, or predetermined goals or performance that have been agreed upon. In this study, company performance is measured through one of the probability ratios, namely, return on assets (ROA). This ROA calculates how much profit a company can generate from its total assets. The higher the ROA value, the better because it means that the company's management is able to minimize all burdens in its business processes properly. This means that the company is a profitable company because it is able to utilize all its potential, including its debts, to generate the highest net profit. From previous research, the factors that significantly or insignificantly affect ROA consist of various kinds, such as costs, cash turnover, accounts receivable turnover and so on. This study aims to determine whether working capital turnover, operational cost ratio, and inventory turnover have an effect on company performance. This research is important for a trading company because these four variables are important aspects of the company. In this study, researchers focused on working capital turnover, operational cost ratios, inventory turnover, which significantly or insignificantly affected ROA. The researchers conducted this research because there were several studies that made doubts, including research by Adnyana and Suardana (2016) which resulted in operating costs and operating income having an effect on ROA, while Lemiyana and Erdah's research (2016) resulted in operating costs- 
income having a negative effect on ROA. Rahayu and Susilowibowo's research (2014) states that inventory turnover has a simultaneous effect on ROA, while Achmad Ishak Setyawan's research results that inventory turnover has no effect on ROA.

\section{METHODS}

According to Sugiyono (2018: 18-19) research according to the level of explanation, there are five levels of research titles, namely titles that are: descriptive, comparative, associative, comparative associative, and structural. The title of comparative-associative research is the title of research that intends to describe and test the hypothesis of the correlation comparison between two or more variables in different samples or populations. In accordance with the title, objectives and benefits of research, the type of research used in this study is a quantitative approach with associative comparative research to determine the effect of working capital turnover, operational cost ratios, inventory turnover on performance UD. Firmansyah. In this study, the type of data used is secondary data. Secondary data is data provided by a data collection agency that can be used by the public. This secondary research data in the form of corporate financial statements UD. Firmansyah 2015-2018. Sources of data used in this study are internal data sources because data sources are taken directly from the company concerned or the place of research. Sugiyono (2015: 55) states that the population is a generalization area consisting of objects or subjects that have certain quantities and characteristics that are determined by researchers to be studied and then drawn conclusions. The population in this study is the financial statement data of UD. Firmansyah Lumajang. According to Sugiyono (2015: 55), the sample is part of the number owned by the population. The sample is part of the overall characteristics of the population. The sample used in this study is UD financial report data. Firmansyah in the last four years, from 2015 to 2018. The data analysis technique for this research is multiple linear regression, and the results must meet the classical assumption tests, including normality test, multicollinearity test, autocorrelation test, heteroscedasticity test.

Data collection methods used in this study were obtained using documentation techniques. Documentation is a technique used in collecting data about what will or want to be researched. In this study, the authors used the documentation method by looking at the financial statements of UD. Firmansyah from 2015-2018. With this method, the authors collect written data, documents, archives and others related to the object of research to obtain secondary data. After obtaining the annual report data, it is continued by analyzing each variable according to the following criteria: Working Capital Turnover, namely the Company's Annual Financial Report which then calculates the number of net sales divided by the average working capital. Operational Cost Ratio, namely in the Company's Annual Financial Statements, which then calculates operating costs divided by operating income times 100\%. Inventory Turnover is the Company's Annual Financial Report which then calculates the cost of goods sold divided by the average inventory. Return On Asset (ROA), which is the Company's Annual Financial Report, which then calculates the amount of net profit divided by total assets multiplied by $100 \%$. After all the variable data in accordance with the research criteria are collected, the process of placing the data in tabular form is then carried out by creating a table containing data on the independent variables, namely working capital turnover, operating cost ratio, inventory turnover and the dependent variable, namely ROA.

\section{RESULTS AND DISCUSSION}

The results of the calculation of working capital turnover, operational cost ratio, inventory turnover, and return on assets: 
Table 1. Calculation Results of Working Capital Turnover

\begin{tabular}{ccc}
\hline Number & Year & Working Capital Turnover $(X 1)$ \\
\hline 1 & 2015 & 0,99 \\
\hline 2 & 2016 & 1,14 \\
\hline 3 & 2017 & 1,10 \\
\hline 4 & 2018 & 1,51 \\
\hline
\end{tabular}

Source: Data processed (2020)

Turnover of working capital is calculated using the formula for net sales divided by average working capital. Net or net sales result from gross or gross sales less various other deductions and deductions. Table 1 shows the results of calculating the average per year.

Table 2. Calculation Results of the Operational Cost Ratio (BOPO)

\begin{tabular}{ccc}
\hline Number & Year & BOPO (X2) \\
\hline 1 & 2015 & 54,27 \\
\hline 2 & 2016 & 67,18 \\
\hline 3 & 2017 & 69 \\
\hline 4 & 2018 & 69,58
\end{tabular}

Source: Data processed (2020)

The Operational Cost Ratio is measured using the BOPO ratio. The ratio of BOPO is calculated using the formula for operating expenses divided by operating income times $100 \%$. Table 2 shows the annual average operating cost ratio.

Table 3. Inventory Turnover Calculation Results

\begin{tabular}{ccc}
\hline Number & Year & Inventory Turnover $(\mathbf{X 3})$ \\
\hline 1 & 2015 & 11,50 \\
\hline 2 & 2016 & 16,39 \\
\hline 3 & 2017 & 15,58 \\
\hline 4 & 2018 & 16,89 \\
\hline
\end{tabular}

Source: Data processed (2020)

Inventory turnover is calculated using the formula for the cost of goods sold divided by the average inventory. The cost of goods sold results from the beginning inventory plus net purchases, less ending inventory. Table 3 shows the results of the calculation of the average inventory turnover per year.

Table 4. ROA Calculation Results

\begin{tabular}{ccc}
\hline Number & Year & ROA (Y) \\
\hline 1 & 2015 & 5,08 \\
\hline 2 & 2016 & 5,66 \\
\hline 3 & 2017 & 5,69 \\
\hline 4 & 2018 & 5,50 \\
\hline
\end{tabular}

Source: Data processed (2020)

Performance is measured using a return on assets (ROA). ROA is calculated using the formula for net income divided by total assets times $100 \%$. To test whether the data used has met these assumptions, this study uses a normal probability plot at the SPSS output. The following figure shows the results of data normality testing using a normal probability plot at the SPSS output. Table 4 shows the results of calculating the average ROA per year. The results of data normality testing in this study are indicated by a probability plot where the points spread around the diagonal line and the distribution follows the direction of the diagonal line, meaning that the regression 
model is suitable for use because it fulfils the assumption of normality, namely the plot spreads over the diagonal line.

Multicollinearity is the occurrence of an almost perfect correlation or relationship between independent variables, which can affect the resulting coefficient on the use of the discriminant analysis model. Multicollinearity can be seen by looking at the VIF (variance inflation factor) and TOL (Tolerance) values, where if the VIF value is not greater or below ten and the TOL value is not less than 0.1 , it can be said that the multicollinearity that occurs is not dangerous or escapes from multicollinearity test. In this study, the independent variables consist of 3 (three) variables, namely working capital turnover, operational cost ratio and inventory turnover in the table above which has a VIF value below ten and a tolerance value above 0.1 , meaning that the independent variable is free from multicollinearity. So the assumptions underlying the second discriminant analysis have been fulfilled so that the two independent variables can be continued to be used in the discriminant analysis model.

The autocorrelation test aims to see whether there is a correlation between a period $\mathrm{t}$ and the previous period $(\mathrm{t}-1)$. In simple terms, regression analysis is to see the effect of independent variables on the dependent variable. The autocorrelation test is only performed on time series data with $\mathrm{N}$ samples being the time period. Some of the statistical tests that are often used are the Durbin-Watson test, the Run Test. A good regression model is a regression model that does not contain autocorrelation if the Durbin-Watson (DW) value lies between du to (4-du). Based on table 6 it shows that the Durbin-Watson value is 1.423 So that it is obtained from the Durbin-Watson table the value of $\mathrm{du}=1.6708$ while the value of $4-\mathrm{du}=2.3292$ means that $\mathrm{dL}<\mathrm{d}<4-\mathrm{du}=1.4064$ $<1.423<2.3292$. So the results are hesitant, in the sense that they cannot conclude that autocorrelation occurs or that autocorrelation does not occur.

Based on the coefficient value obtained, a regression equation can be formulated to see the effect of working capital turnover, operating cost ratio, and working capital turnover on UD performance. Firmansyah as follows: $\mathrm{Y}=3,702-0,481(\mathrm{X} 1)+0,049(\mathrm{X} 2)-0,055(\mathrm{X} 3)$. This equation shows that the variables of working capital turnover and inventory turnover have a coefficient in a negative direction, while the operating cost ratio variable has a coefficient in a positive direction. The explanation of the multiple linear regression equation above is as follows: Constants, the constant value in the regression equation shows a value of 3.702 , which meaning that if all the independent variables are absent or the value is 0 , then the company performance (Y) the value is 3.702. The coefficient $\beta 1$, the coefficient value of working capital turnover for variable $\mathrm{X} 1$ is 0.481 in a negative direction. So it can be assumed that for each decrease in working capital turnover of 1 (one), company performance (ROA) will decrease by -0.481 . Coefficient $\beta 2$, the coefficient value of the ratio of operating costs for variable X2 is 0.049 in a positive direction. So it can be assumed that every increase in the ratio of operating costs by 1 (one), company performance (ROA) will increase by 0.049 . The coefficient $\beta 3$, the value of the receivables turnover coefficient for variable X3 is 0.055 in a negative direction. It can be assumed that every 1 (one) decrease in accounts receivable turnover, company performance (ROA) will decrease by 0.055 .

Through the t-test, this study shows that working capital turnover and inventory turnover do not have a significant effect on company performance, while the ratio of operating costs has a significant effect on company performance. The purpose of doing the $\mathrm{F}$ test is to test whether the regression model is fit for use or fit. The $\mathrm{F}$ test can be done by looking at the significance value of $\mathrm{F}$ in the regression output with a significance level of $0.05(\alpha=5 \%)$. If the probability value is greater than $\alpha$, it means that the regression model is not fit. Meanwhile, if the significance value is smaller than $\alpha$, it means the regression model is fit. Based on table 9 , it is known that the simultaneous test results show a significant value of 0.045 . This significant value is less than 0.05 . It can be assumed that the independent variables (working capital turnover, operating cost ratio, 
and inventory turnover) have a simultaneous effect on the dependent variable (company performance).

Based on the results of the t-test, the t value has a negative direction of 1.289 with a significant value of 0.204 . At the same time, the $t$ table value is obtained by looking at the $t$ table. The significant value is greater than the probability value $(\alpha)=5 \%$ or the value $0.204>0.05$, then H1 is rejected and $\mathrm{H} 0$ is accepted. Probability or $(\alpha / 2 ; \mathrm{n}-\mathrm{k}-1)=(0.05 / 2 ; 48-3-1)=(0.025 ; 44)=$ 2.015. Then the variable $\mathrm{X} 1$ is known to be $\mathrm{t}$ table which is 2.015 . So $\mathrm{t}$ count <ttable or 1.289 $<2.015$, it can be concluded that the variable X1 does not have a significant effect on $\mathrm{Y}$. The company uses working capital for its operational activities. The funds released by the company are expected to return for further operational activities - the results of the calculation of the working capital turnover of UD. Firmansyah showed an increase in 2016 but decreased with a value of 1.10 in 2017 and increased again in 2018 of 1.51. If the working capital turnover period is short, the working capital needed is getting smaller, and vice versa, if the working capital turnover period is getting longer, the working capital needed will be even greater.

Based on the results of the hypothesis test (t-test), it is known that working capital turnover has no significant effect on company performance using ROA as a proxy. This is due to the sale of UD. Firmanysah is low, so the result is that working capital rotates slowly and the profits are not too high. So that the capital that has been issued does not quickly return to cash and can result in UD operational activities. Firmansyah also slowed down. As a result of UD. Firmansyah cannot improve company performance, and working capital turnover is not effective. This can be overcome by increasing sales of cowhide, goatskin or increasing sales of both. The results of this study are supported by previous researchers Siswanto (2010) with the research title Analysis of the Effect of Working Capital Turnover on Return On Assets (ROA) in Real Estate and Property Companies Listed on the Indonesia Stock Exchange, stating that working capital turnover does not have a significant influence on ROA on real estate and property companies listed on the IDX. However, the results of this study are not in line with Nuraini's research, Syera Ayu (2015) with the research title The Effect of Working Capital Turnover on Return On Assets (Property and Real Estate Companies Listed on the Indonesia Stock Exchange, states that working capital turnover has a significant effect on ROA.

Based on the results of the $\mathrm{t}$-test, the $\mathrm{t}$ value has a positive direction of 2.758 with a significant value of 0.008 . At the same time, the $t$ table value is obtained by looking at the $t$ table. The significant value is smaller than the probability value $(\alpha)=5 \%$ or the value $0.008<0.05$, then $\mathrm{H} 1$ is accepted and H0 is rejected. Probability or $(\alpha / 2 ; \mathrm{n}-\mathrm{k}-1)=(0.05 / 2 ; 48-3-1)=(0.025 ; 44)=$ 2.015. Then the variable $X 2$ is known to be $t$ table which is 2.015 . So tcount $>t$ table or 2.758> 2.015 , it can be concluded that the variable X2 has a significant effect on $\mathrm{Y}$ - the results of the calculation of the operational cost ratio of UD. Firmansyah shows an increase from year to year, and the increase starts from 2016 to 2018. The increase in operating costs on operating income shows that companies spend more on operating costs in generating profits. If operating costs increase, not followed by an increase in operating income, it will result in a reduction in ROA. Based on the results of hypothesis testing ( $t$-test), it is known that operational costs have a significant effect on company performance (ROA) but are negative. Expenditures for activities at UD. Firmanysah increased due to expenses used to finance repairs, maintenance of office inventory, and also financing repairs, transportation maintenance during the activities of UD company. Firmansyah. At UD. Firmansyah can be seen that the costs during operational activities are higher than the operating income so that it can have an impact on the profits obtained by the company if you want to increase company profits, UD. Firmansyah can make the maximum possible emphasis on financing. The results of this study were supported by previous researchers, namely Adnyana and Suardana (2016) with the title of the study The Effect of Operating CostsOperating Income, Asset Growth and Non-Performing Loans on ROA, stating that operating costsoperating income and non-performing loans have a significant effect on ROA. Meanwhile, Lemiyana and Erdah's (2016) research entitled The Effect of NPF, FDR, BOPO on Return On 
Assets (ROA) in Islamic Commercial Banks, states that NPF, FDR has no effect on ROA. Meanwhile, BOPO has an influence on ROA but is negative.

Based on the results of the t-test, the $t$ value has a negative direction of 1.001 with a significant value of 0.322 . At the same time, the $t$ table value is obtained by looking at the $t$ table. The significant value is greater than the probability value $(\alpha)=5 \%$ or the value $0.322>0.05$, then $\mathrm{H} 1$ is rejected and H0 is accepted. Probability or $(\alpha / 2 ; \mathrm{n}-\mathrm{k}-1)=(0.05 / 2 ; 48-3-1)=(0.025 ; 44)=$ 2.015. Then the variable $\mathrm{X} 3$ is known to be $\mathrm{t}$ table which is 2.015 . So $t$ count <ttable or 1.001 $<2.015$, it can be concluded that the X3 variable has no significant effect on Y. The results of the calculation of inventory turnover have increased from 2015 to 2016 but decreased in 2017 and increased again in 2018 - so low rotation. Inventory has decreased, which results in the company not working efficiently which will result in excess stock inventory which will cause more costs to be used for maintaining product quality which has an impact on reducing company profits. Based on the results of hypothesis testing (t-test), it is known that inventory turnover has no significant effect on company performance (ROA). At UD. Firmansyah purchases its trade products that are greater than sales which results in the inventory or stock in the warehouse rotating very slowly which results in the company having to spend more costs which will be used to maintain product quality. Slow inventory turnover resulted in profit at UD. Firmansyah decreased so that ROA also decreased. This can be overcome by estimating the demand for the stock of goods by looking at market changes and looking at the previous year's sales data to reference the stock of goods in the following year. The results of this study were supported by previous researchers, namely Setyawan, Achmad Ishak (2009) with the research title The Effect of Working Capital Turnover (Cash Turnover, Accounts Receivable Turnover and Inventory Turnover) on the Profitability of Manufacturing Companies Listing on the IDX for the 2005-2007 Period, stated that cash turnover and accounts receivable turnover has a significant effect on ROA. Meanwhile, the inventory turnover has no effect on ROA. However, the results of this study are not in line with the research of Rahayu and Susilowibowo (2014) with the title of research The Effect of Cash Turnover, Accounts Receivable Turnover and Inventory Turnover on Profitability of Manufacturing Companies, stating that cash turnover, accounts receivable turnover and inventory turnover simultaneously influence profitability (ROA).

Based on the results of the $\mathrm{F}$ test, it can be seen that simultaneously working capital turnover, operational cost ratio, and inventory turnover have a significant effect on the performance of the UD company. Firmansyah for the 2015-2018 period because the sig value of 0.045 is smaller than 0.05 , which means that if the working capital turnover, operating cost ratio, and inventory turnover move together, it will have a positive impact on company performance. So it is important to manage working capital turnover, operational cost ratio, and inventory turnover effectively to influence company performance which does not rule out if the three variables are managed effectively it will result in increased profits or company performance from year to year.

\section{CONCLUSION}

The results of hypothesis testing on the effect of working capital turnover variables on company performance (ROA) indicate that there is no significant effect of working capital turnover on company performance (ROA). The results of hypothesis testing on the effect of the ratio of operational costs on company performance (ROA) indicate that there is a significant effect of operational costs on company performance (ROA). The results of hypothesis testing on the effect of the inventory turnover variable on company performance (ROA) show that there is no significant effect on the company's performance (ROA). 


\section{REFERENCE}

Halim, A. (2015) . Manajemen Keuangan Bisnis: Konsep Dan Aplikasinya. Jakarta: Mitra Wacana Media.

Adnyana, C. S., \& Suardana, K. A. (2016). Pengaruh Biaya Operasional-Pendapatan Operasional, Pertumbuhan Aset Dan Non Performing Loan Terhadap Return On Asset. E-jurnal Akuntansi Universitas Udayana.

Ernawati, F. (2015). Pengaruh Biaya Operasional Terhadap Laba Bersih Dengan Perputaran Persediaan Sebagai Variabel Pemoderasi. Jurnal Ilmu Dan Riset Manajemen. 4(9).

Kusumo, C.Y., \& Darmawan, A. (2018). Pengaruh Perputaran Modal Kerja, Ukuran Perusahaan, Dan Diversifikasi Terhadap Profitabilitas. Jurnal Akuntansi Bisnis. 57(1). 83-89.

Kuswadi. (2005). Meningkatkan Laba Melalui Pendekatan Akuntansi Keuangan Dan Akuntansi Biaya. PT Alex Media Komputindo.

Lemiyana., \& Litriani, E. (2016). Pengaruh NPF, FDR, BOPO Terhadap Retrun On Asset Pada Bank Umum Syariah. I-Economic.

Mega, U.S. (2016). Peran Knowledge Sharing Dalam Memperkuat Pengaruh Kompetensi Dan Rotasi Kerja Untuk Meningkatkan Kinerja SDM.

Nuraini, S. A., Hidayati, K., \& Rosyafah, S. (2015). Pengaruh Perputaran Modal Kerja Terhadap Retrun On Asset. Jurnal Akuntansi UBHARA.

Rahayu, E., \& Susilowibowo, J. (2014). Pengaruh Perputaran Kas, Perputaran Piutang Dan Perputaran Persediaan Terhadap Profitabilitas Perusahaan Manufaktur. Jurnal Ilmu Manajemen.

Setyawan. A. I. (2009). Pengaruh Peputaran Modal Kerja (Perputaran Kas, Perputaran Piutang, Dan Perputaran Persediaan) Terhadap Profitabilitas.

Setyawan. A. I. (2009). Pengaruh Peputaran Modal Kerja (Perputaran Kas, Perputaran Piutang, Dan Perputaran Persediaan) Terhadap Profitabilitas.

Siswanto. (2010). Analisis Pengaruh Perputaran Modal Kerja Terhadap Return On Asset (ROA) Pada Perusahaan-Perusahaan Real Estate dan Property yang Terdaftar Di Bursa Efek Indonesia. SP- Accountacy.

Sugiyono. (2015). Metode Penelitian Dan Pengembangan (Research And Development/R\&D). Bandung: Alfabet.

Sugiyono. (2018). Metode Penelitian Bisnis. Bandung: Alfabeta 